\title{
エレクトロオーガニックケミストリーLXVII. 電極反応によるアルコール水酸基の変換
}

\author{
庄野 達哉*, 松村 功啓*, 林 重衛*, 且井みき子* \\ Electroorganic Chemistry LXVII. \\ Electrochemical Transformation of Alcoholic Hydroxyl Group
}

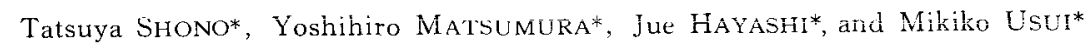

\section{1 緒言}

スルフィド 1 は電極反応により容易に酸化されて 2 の ごときカチオン活性種を生成する゙'.

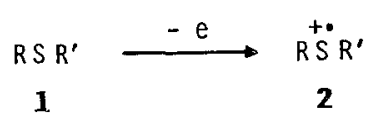

われわれはこのような力チ才ン活性㮔を有機合成儿有 效に利用寸ることを目的の1つとして研究を执こない， 既にベンゾニトリル(PhCN) 溶媒中チオアニソール $\left(\mathrm{PhSCH}_{3}\right)$ から生成する力チオン活性種をメディエータ 一として用いれば 2 級アルコール3をケトン4 亿変換で きること老報告した(Path a, Scheme 1) ${ }^{2}$. 今回, 1 級または 2 級アルコール 3 括よび 1 の塩化メチレン $\left(\mathrm{CH}_{2} \mathrm{Cl}_{2}\right)$ 溶液に通電することにより篮化物 5 が生成 する(path b, Scheme 1)ことを見いだした。

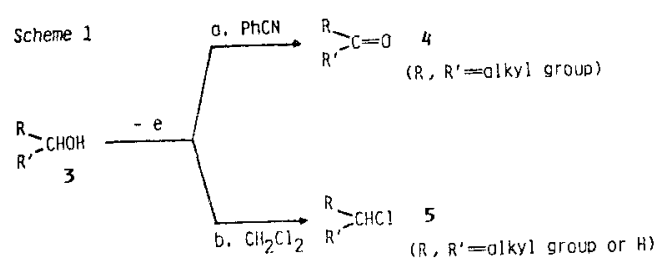

さらに,トリフェニルホスフィンの電極酸化により 生成する力チオン活性種も3から5 ○の変換に利用でき ることあ見いだしたので併せて報告する。

\section{2 実 験}

反応七ルに1 (15 mmol), p・トエンスルホン酸テト ラエチルアンモニウム ( $\left.\mathrm{Et}_{4} \mathrm{NOTs}\right)(5 \mathrm{mmol}), 3(10 \mathrm{~m}$ $\mathrm{mol})$, お文ざ $\mathrm{CH}_{2} \mathrm{Cl}_{2}\left(10 \mathrm{~cm}^{3}\right)$ を大れる。隔膜は使用せ ず，反応中，七ルは外部から冷水で泠却する。 $0.2 \mathrm{~A} の$ 定電流で $3-5 \mathrm{~F} / \mathrm{mol}$ 通電後, 反応掖を水に注ぎ, $\mathrm{CH}_{2}-$ $\mathrm{Cl}_{2}$ 抽出して乾燥, 蒸溜して生成物を単離し分光学的方 法で同定した。收率はガスクロマトグラフで求めた。混

* 京都大学工学部合成化学教室 ( 606 京都市左京区吉田本町) Department of Synthetic Chemistry, Faculty of Engineering, Kyto University (Yoshida, Sakyo-ku, Kyoto 606)
合溶媒を使用する反応，ジオールおよびトリフェニルホ スフィンの反忘も同様の条件で反忘を行なった。

\section{3 結果と考察}

3. 1 1級および 2 級アルコール 3 のクロル化

ジフェニルスルフィド (PhSPh) の存在下, 3 の $\mathrm{CH}_{2}-$ $\mathrm{Cl}_{2}$ 溶液に通電して生成する 5 の收率孝 Table 1 亿示 した。また， $\mathrm{CH}_{2} \mathrm{Cl}_{2}$, ク口口ホルム $\left(\mathrm{CHCl}_{3}\right)$ および四 塩化炭素 $\left(\mathrm{CCl}_{4}\right)$ のア七トニトリル $\left(\mathrm{CH}_{3} \mathrm{CN}\right)$ 溶媒を 用いた結䒜も Table 1 に示した。

このクロル化反心についてはPhSPhが存在しないと まったくクロル化が抗こらないこと，さらに，スルフィ ドり構造を変化させるとクロル化り收率が（2）式に示 すごとく大きく变化したことから，反応はスルフィドの 電極酸化で生成するカチオン種にアルコールが玫撃し, その結果生成するスルホキソニウムイオン6にタロルア ニオンが攻撃してクロル化が怙こると考えら机る（path

\begin{tabular}{|c|c|c|c|}
\hline rแก & ROH (10 mmol) & F/mol & $\begin{array}{l}\text { Yield of } \\
\left.\text { RC] }(z)^{C}\right)\end{array}$ \\
\hline 1 & \multirow{4}{*}{$\mathrm{CH}_{3}\left(\mathrm{CH}_{2}\right)_{6} \mathrm{CH}_{2} \mathrm{OH}$} & 4 & 95 \\
\hline 2 & & 3.7 & $56^{d)}$ \\
\hline 3 & & 3.7 & $79^{e)}$ \\
\hline 4 & & 3.7 & $57^{f)}$ \\
\hline 5 & $\mathrm{CH}_{3}\left(\mathrm{CH}_{2}\right)_{2}{ }^{-\mathrm{CH}_{2} \mathrm{OH}}$ & 4 & 82 \\
\hline 6 & $\mathrm{C}_{6} \mathrm{H}_{5}\left(\mathrm{CH}_{2}\right)_{2} \mathrm{CH}_{2} \mathrm{OH}$ & 5 & 90 \\
\hline 7 & $\mathrm{C}_{2} \mathrm{H}_{5} \mathrm{OCH}_{2} \mathrm{CH}_{2} \mathrm{OH}$ & 3 & 82 \\
\hline 8 & $\underset{\mathrm{CH}}{\mathrm{CH}_{3}\left(\mathrm{CH}_{2}\right)_{5} \mathrm{CHCH}_{3}}$ & 4 & 75 \\
\hline 9 & $\mathrm{CH}_{3}\left(\mathrm{CH}_{2}\right)_{6}{ }_{\mathrm{OH}}^{\mathrm{CHC}_{2} \mathrm{H}_{5}}$ & 4 & $E g$ \\
\hline 10 & & 4 & troce \\
\hline $1 I$ & & 4 & 55 \\
\hline
\end{tabular}

o) Solvent: $\mathrm{CH}_{2} \mathrm{Cl}_{2}(15 \mathrm{~m}$ !), Alcohol $110 \mathrm{mmol})$, PhsPh (15 mol), b) Anode and cothode moterials: Carbon rods (8mi ). C) Yields were obtoined by glc method. d) Solvent: $\mathrm{CH}_{3} \mathrm{CN}(15 \mathrm{ml})$ containing $\mathrm{CH}_{2} \mathrm{Cl}_{2}$ (20 mol), Alcohol (10 mol), PhSPh( $15 \mathrm{~mol}$ ). e) Solvent: $\mathrm{CH}_{3} \mathrm{CN}(15 \mathrm{ml})$ contaln!ng $\mathrm{CHCl}_{3}(20 \mathrm{mmol})$, A] cohol (5mol), Prisph(7.5 amol). f) Solvent : $\mathrm{CH}_{3} \mathrm{CN}(15 \mathrm{ml})$ contaln!ng $\mathrm{CCl}_{4}(20 \mathrm{ml})$, Al cohol (5 mol), PhSPh (7. 5 mol). 
c. Scheme 2). しかし, 6 の生成ルートとして, クロル アニオンの酸化で生成するクロルカチオンがスルフィド と反応しクロルスルホニウムイオン゙を与える径路 (path d, Scheme 2) も否定はできない.

$$
\mathrm{CH}_{3}\left(\mathrm{CH}_{2}\right)_{7} \mathrm{OH} \frac{4 \mathrm{~F} / \mathrm{mol}}{\mathrm{CH}_{2} \mathrm{Cl}_{2}, \mathrm{RSR^{ \prime }}} \mathrm{CH}_{3}\left(\mathrm{CH}_{2}\right)_{7} \mathrm{Cl}
$$

$\begin{array}{ccc}\text { R } & \mathrm{R}^{\prime} & \text { Yield (z) } \\ \text { Ph } & \text { Ph } & 95 \\ \text { Ph } & \mathrm{CH}_{3} & 33 \\ \text { Ph } & \mathrm{CH}\left(\mathrm{CH}_{3}\right)_{2} & 21 \\ \mathrm{CH}_{3}\left(\mathrm{CH}_{2}\right)_{7} & \mathrm{CH}_{3} & <1\end{array}$

Schere 2

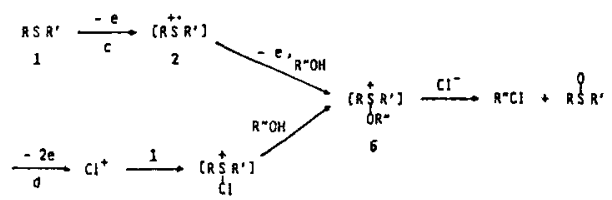

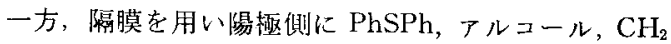
$\mathrm{Cl}_{2}$ を存在させて通電してもアルコールのクロル化が㧤 こらなかったことから、クロルアニオンの供給源として は $\mathrm{CH}_{2} \mathrm{Cl}_{2}$ の陰極還元 ${ }^{4)}$ が考えられる. $\mathrm{CHCl}_{3}$, および $\mathrm{CCl}_{4}$ を用いた反応の場合にもこれらの電極還元でクロ ルアニオンが生成すると考えられる ${ }^{5}$.

次いで，クロルアニオンが 6 に求核攻撃する段階の立 体化学を光学活性 2-オク夕ノールを用いて㭘討した ((3) 式). 生成物である 2 タロルオクタンの光学純度 （oy）測定すると $94.6 \%$ であった．出発物の立体配惪 は $\mathrm{S}$ 体であり生成物のそれは $\mathrm{R}$ 体であったのでこの反 応はほとんど完全に $\mathrm{S}_{\mathrm{N}} 2$ 機構で進んでいると言える。ジ メチルブロモスルホニウムブロミドによってアルコール がブロム化されることが報告されているが6)，このブロ ム化反忘の機構とまったく同様に電極反応によるクロル 化反応に㧍いても7の遷移状態を経ていると考えられる。

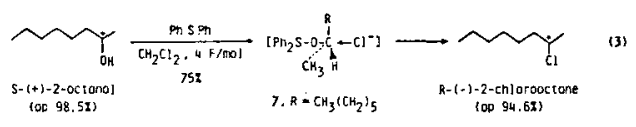

一方, ベンジル位水酸基のクロル化は $\mathrm{CH}_{2} \mathrm{Cl}_{2}$ 中では 達成できなかった，すなわち， $\mathrm{PhSPh}$ と $8 の \mathrm{CH}_{2} \mathrm{Cl}_{2}$ 溶液に通電すると主生成物にエチルベンゼンが生成する， これは隔膜を使用していないためにタロル化生成物 9 が 還元されたものと考えられる。しかし， $\mathrm{CHCl}_{3}$ を溶媒 に用いると 9 が70\%の収率でえられた ((4) 式).

*トリフェニルホスフィンの酸化で生成するカチオン種へ の種々の求核郕の反応は報告されているて



3. 2 トリフェニルホスフィンとアルコール 3 との反 応

トリフェニルホスフィンも PhSPh と同様の作用をす ることが明らかになっだ1 (( 5$)$ 式).

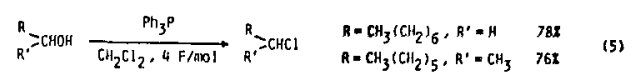

\section{3 ジオールの反応}

1,4-および 1,5-ジオールは $\mathrm{CH}_{2} \mathrm{Cl}_{2}$ 中 $\mathrm{PhSPh} の$ 存 在下の電極反応で環状エーテルを与える（(6) 式（7)

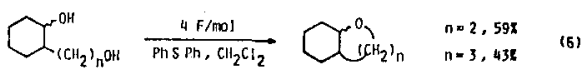
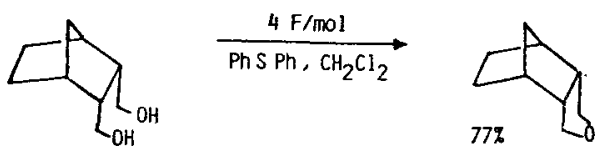

(7)

式).

\section{4 結 語}

反応機構の検討，他のアルコールおよびジオールへの 応用などの嶵題は今後引き続き研究する予定であるが, 溶谋を選択することによりアルコールからまったく異な る種類の化合物が選扑的に生成するという本論文の結果 は有機合成化学的見地から興味深い。

\section{文献}

1) T. Shono in "S. Patai (ed), The Chemistry of Ethers, Hydroxyl Groups and Their Sulfur Analogues", Part 1, Ch. 8, John Wiley \& Sons, 1980.

2) T. Shono, Y. Matsum dra, M Mizoguchi, and J. Hayashi, Tetrahedron Lett. 1979, 3861

3) E. J. Corey, C. U. Kim, and M. Takeda, Tetrahedron Lett. 1972, 4339.

4) H. Siegerman in "N. L. Weinberg (ed), Techniques of Electroorganic Synthesis", Part 2, p. 828, John Wiley \& Sons, 1974.

5) M. M. Baizer and J. L. Chruma, J. Org. Chem. 37, 1951 (1972).

6) N. Furukawa, T. Inoue, T. Aida, and S. Oae, $J$. Chem. Soc., Chem. Commun. 1973, 212.

7) H. Ohmori, S. Nakai, M. Sekiguchi, and M. Masui, Chem. Pharm. Bull. 28, 910 (1980).

(Received Oct. 4, 1982 ; Accepted Oct. 25, 1982) 